\title{
Dietary factors and stomach cancer mortality
}

\author{
LT Ngoan",', T Mizoue', Y Fujino', N Tokui' and T Yoshimura' \\ 'Department of Clinical Epidemiology, Institute of Industrial Ecological Sciences, University of Occupational and Environmental Health, I-I Iseigaoka, \\ Yahatanishi-ku, Kitakyushu 807-8555, Japan
}

\begin{abstract}
The present study examined the relationship between stomach cancer and the low intake of fresh fruit and vegetables and/or a high intake of pickled, preserved or salted foods and frequent use of cooking oil. During 139390 person-year of follow-up of over 13000 subjects, I 16 died from stomach cancer. Using a Cox proportional hazards - regression analysis of relative risk $(\mathrm{RR}, 95 \% \mathrm{Cl})$ controlling for age, sex, smoking and other dietary factors, a significant decline was found with a high consumption of green and yellow vegetables ( $R R=0.4,95 \% \mathrm{Cl}=0.2-0.9$ ). Reductions of between 40 and $50 \%$ were also observed with a high consumption of fresh foods (fruit, cuttle fish, tofu, and potatoes), but these associations were not statistically significant. The risk was significantly increased by the high consumption of processed meat $(\mathrm{RR}=2.7,95 \% \mathrm{Cl}=1.0$ 7.4) and by the frequent use of cooking oil ( $R R=4.0,95 \% \mathrm{Cl}=1.3-1 \mid$. 8$)$. The high consumption of pickled food and traditional soups also increased risk, but not significantly. The findings suggest that a diet high in salt and low in vitamins may be associated with an increase in stomach cancer.

British Journal of Cancer (2002) 87, 37-42. doi:I0.1038/sj.bjc.66004I5 www.bjcancer.com

(c) 2002 Cancer Research UK
\end{abstract}

Keywords: dietary factors; stomach cancer; mortality

Stomach cancer was the second most common cause of death from cancer in both sexes in 1990 throughout the world (Pisani et al, 1999). In that year, the highest incidence in the world were found in Yamagata, Japan, age standardised incidence rate (ASR) 95.5 and 40.1 per 100000 in males and females, respectively. These rates were about four times higher than those found in Hawaiian - Japanese (ASR 21.5 and 10.4 per 100000 in males and females, respectively) (Parkin et al, 1997), pointing to the importance of environmental factors. Dietary substances have long been considered to be important risk factors of stomach cancer (Davis, 1989; Nomura, 1996).

Results from previous studies suggested that a diet rich in vitamin $\mathrm{C}$ was protective, whereas a diet high in salt might increase the risk of stomach cancer (Mirvish et al, 1972; Raineri and Weisburger, 1975; Joossens et al, 1996; Zhang et al, 2002). Sources of vitamin $\mathrm{C}$ include fresh foods, such as green and yellow vegetables, fruit and other fresh foods, while salt ingestion is from processed, pickled, preserved, salted foods, and also seasoning (Kagawa, 1991). Salt is used during processing and preserving, and cooking oil is frequently used in food preparation. The purpose of our present study was to examine the roles in relation to stomach cancer of a diet low in fresh fruit and vegetables or high in pickled, preserved or salted foods and also of frequent use of cooking oil.

\section{MATERIALS AND METHODS}

\section{Study population}

Our cohort study was started in Fukuoka Prefecture in 1986-89, and the follow-up method has been described elsewhere (Fujino

\footnotetext{
*Correspondence: LT Ngoan; E-mail: letngoan@med.uoeh-u.ac.jp Received 12 November 200I; revised 20 March 2002; accepted 10 April 2002
}

et al, 2001; Mizoue et al, 2000; Utoguchi et al, 1997). The number of subjects who were invited to participate and fill in a self-administered questionnaire was 15417 . Among these, 882 subjects did not reply, 1237 did not completely answer all items of this questionnaire, 9 were lost in follow-up, 10 made errors in their follow-up information, and the ages of 29 was unknown. After excluding these subjects, 13250 (5917 males and 7333 females) aged over 15 had completed the self-administered questionnaire at base line and provided the food frequency details of 25 common food items, remained eligible and were then followed up to 1999. During the 139390 person-year of follow-up, 116 subjects died from stomach cancer, of which three cases were coded 151.0 (cardia), one case 151.1 (pylorus), two cases 151.2 (pyloric antrum), one case 151.3 (fundus), five cases 151.4 (body of stomach), one case 151.8 (other), and 103 cases 151.9 (unspecified) - (ICD-9). All histological types of stomach cancer cases were analysed together.

\section{Exposure information}

Among 254 items on the self-administered questionnaire, participants were asked to provide their dietary habits regarding the food frequency consumption, such as twice or more per day, once per day, 2-4 times per week, 2-4 times per month, and seldom or never. For subjects recruited in 1986, their frequency of consumption of fresh meat, fish, cuttle fish, tofu, liver, fresh milk, eggs, seaweed, green and yellow vegetables, fruit, potatoes, margarine, use of cooking oil, Japanese miso soup, deep-boiled food, and green tea drinking was obtained. Thereafter, in 1987 and 1989, other food items, such as processed meat and fish, soymilk, milk products, other vegetables, Japanese suimono soup, pickled food, salted food, and sweet cakes, were added to the self-administered questionnaire to collect further dietary information. Among 8161 study subjects recruited in 1987 and 1989, the percentage of subjects who stated that their dietary consumption for these new 
food items was 93.4-97.4\%. Among 13250 eligible subjects in the whole cohort, the percentage of subjects who stated their dietary consumption of the remaining food items was $91.1-97.3 \%$.

\section{Statistical analysis}

We used the age of subjects in 1987 to categorize age groups as $15-29,30-39,40-49,50-59,60-69$, and $70+$. We counted person-years of follow-up for each subject from the starting time of this follow-up until the date of death for 1627 fatal cases; until the date of migration outside the study areas for 1174 subjects; and for 10449 subjects to the end of last follow-up.

We classified three levels of exposure: low, medium and high, for all food items, except for eggs and other vegetables due to the small number of stomach cancer cases in females at the lowest level (seldom or never). Among these food items, because subjects consumed them at different frequencies, the five levels of food consumption obtained from the self-administered questionnaire were grouped into three levels, according to individual food. For cuttle fish and liver, the low level of exposure was seldom or never, medium was 2-4 times per month, and high was 2-4 times or more per week. For eggs and other vegetables, low exposure level was 2-4 times or less per week and high level was once or more per day (two levels). For fruit, Japanese miso soup, deep-boiled food, and pickled food, the low exposure level was 2-4 times or less per week, medium was once per day, and high was twice or more per day. For the remaining food items, low exposure level was 2-4 times or less per month, medium was 2-4 times per week, and high was once or more per day (Tables 2 and 3 ).

A Cox proportional hazards-regression analysis was used to estimate relative risk and 95\% confidence interval (RR and 95\% CI) (STATA, 1999). The other factors are tobacco smoking (current, former, and currently not smoking), alcohol (current or currently not drinking), history of chronic gastric symptoms (yes or no), occupation (permanent or nonpermanent work), and coffee drinking (daily or occasionally). These factors control possible confounding factors (Haenszel et al, 1972; Hoey et al, 1981; Hisashige et al, 1983; Jeyaratnam et al, 1987; Kono et al, 1988; Yin et al,
1989; Hirayama, 1990; Kneller et al, 1990; Une et al, 1995; You et al, 1995; Galanis et al, 1998).

Stomach cancer patients who died during the first years of the follow-up might have changed their dietary habits at the time of registration. Therefore, the data was analysed, both including and excluding the first three years of follow-up.

\section{RESULTS}

Characteristics of the study subjects at base line are presented in Table 1. A total of 116 cases of deaths from stomach cancer were identified, 77 males and 39 females. The mean age of non-stomach cancer patients when compared to stomach cancer patients was younger by more than 10 years in both sexes. There was no significant association with stomach cancer and gastric symptoms $(\mathrm{RR}=1.2,95 \% \quad \mathrm{CI}=0.6-2.4)$, coffee drinking $(\mathrm{RR}=1.0,95 \%$ $\mathrm{CI}=0.9-1.1)$, alcohol consumption $(\mathrm{RR}=1.0,95 \% \mathrm{CI}=0.9-1.1)$, or occupation $(\mathrm{RR}=1.0,95 \% \mathrm{CI}=0.9-1.1)$ in this study population, so these factors were excluded from the final model. The high consumption of green and yellow vegetables was similar in cases (35.5\%) and non-cases (35.2\%), although among cases, it was higher $(47.6 \%)$ in the first six years of follow-up than in the later period $(27.7 \%)$. A greater proportion of subjects with a high fruit consumption was found among cases $(17.7 \%)$ than non-cases $(11.5 \%)$, and also in the first six years of follow-up (20.6\%) than in the later period (16.2) among cases.

Age adjusted RR, 95\% CI by gender is presented for individual foods in Table 2. A high consumption of processed meat was associated with a significantly increased the risk of stomach cancer in males $(\mathrm{RR}=3.4,95 \% \mathrm{CI}=1.4-8.1, P$ for trend $=0.07)$ but not in females $(\mathrm{RR}=1.9,95 \% \mathrm{CI}=0.6-6.3)$. An increased $\mathrm{RR}$ was seen with the frequent use of cooking oil $(2.7,95 \% \mathrm{CI}=1.2-6.1, P$ for trend $<0.05$ in males and $2.2,95 \% \mathrm{CI}=0.8-6.0, P$ for trend $=0.08$ in females). A high consumption of pickled foods was associated with a significantly increased risk of stomach cancer in males $(\mathrm{RR}=2.6,95 \% \mathrm{CI}=1.1-5.8, P$ for trend $<0.05)$ but not in females $(\mathrm{RR}=1.1,95 \% \mathrm{CI}=0.3-4.3)$. A high consumption of suimono soup significantly increased the risk of stomach cancer in both males

Table I Characteristics of the subjects at base line

\begin{tabular}{|c|c|c|c|c|c|c|}
\hline \multirow[b]{2}{*}{ Characteristics } & \multicolumn{2}{|c|}{ Males } & \multicolumn{2}{|c|}{ Females } & \multicolumn{2}{|c|}{ Both sexes } \\
\hline & Cases & Non-cases & Cases & Non-cases & Cases & Non-cases \\
\hline Number & 77 & 5840 & 39 & 7294 & $116^{\mathrm{a}}$ & 13134 \\
\hline $\begin{array}{l}\text { Mean age } \pm \text { St. Dv. } \\
\text { Age range (Min }- \text { Max) }\end{array}$ & $\begin{array}{c}63.1 \pm 9.6 \\
39-80\end{array}$ & $\begin{array}{l}52.0 \pm 13.3 \\
15-96\end{array}$ & $\begin{array}{l}66.2 \pm 10.5 \\
46-86\end{array}$ & $\begin{array}{l}53.0 \pm 13.6 \\
20-92\end{array}$ & $\begin{array}{l}64.2 \pm 9.9 \\
39-86\end{array}$ & $\begin{array}{c}52.6 \pm 13.4 \\
15-96\end{array}$ \\
\hline $\begin{array}{l}\text { Mean person-year } \pm \text { St. Dv. } \\
\text { Person-year range (Min }- \text { Max) }\end{array}$ & $\begin{array}{l}6.5 \pm 3.4 \\
0.2-11.6\end{array}$ & $\begin{array}{l}10.4 \pm 3.1 \\
0.01-12.3\end{array}$ & $\begin{array}{l}7.7 \pm 3.5 \\
0.2-12.0\end{array}$ & $\begin{array}{l}10.7 \pm 2.8 \\
0.01-12.3\end{array}$ & $\begin{array}{l}6.9 \pm 3.4 \\
0.2-12.0\end{array}$ & $\begin{array}{l}10.5 \pm 2.9 \\
0.01-12.3\end{array}$ \\
\hline $\begin{array}{l}\text { Occupation: permanent work } \\
\text { Per cent (\%) }\end{array}$ & $\begin{array}{c}15 \\
(19.5)\end{array}$ & $\begin{array}{l}2459 \\
(42.1)\end{array}$ & $\begin{array}{c}3 \\
(7.7)\end{array}$ & $\begin{array}{l}1198 \\
(16.4)\end{array}$ & $\begin{array}{l}18 \\
(15.5)\end{array}$ & $\begin{array}{l}3657 \\
(27.8)\end{array}$ \\
\hline $\begin{array}{l}\text { History of gastric symptoms } \\
\text { Per cent (\%) }\end{array}$ & $\begin{array}{c}8 \\
(10.4)\end{array}$ & $\begin{array}{l}612 \\
(10.5)\end{array}$ & $\begin{array}{c}1 \\
(2.6)\end{array}$ & $\begin{array}{l}647 \\
(8.9)\end{array}$ & $\begin{array}{c}9 \\
(7.8)\end{array}$ & $\begin{array}{l}1259 \\
(9.6)\end{array}$ \\
\hline $\begin{array}{l}\text { Daily coffee drinking } \\
\text { Per cent (\%) }\end{array}$ & $\begin{array}{c}13 \\
(16.9)\end{array}$ & $\begin{array}{l}2157 \\
(36.9)\end{array}$ & $\begin{array}{c}11 \\
(28.2)\end{array}$ & $\begin{array}{l}2399 \\
(32.9)\end{array}$ & $\begin{array}{c}24 \\
(20.7)\end{array}$ & $\begin{array}{l}4556 \\
(34.7)\end{array}$ \\
\hline $\begin{array}{l}\text { Currently drinking alcohol } \\
\text { Per cent (\%) }\end{array}$ & $\begin{array}{c}54 \\
(70.1)\end{array}$ & $\begin{array}{l}3783 \\
(64.8)\end{array}$ & $\begin{array}{c}19 \\
(48.7)\end{array}$ & $\begin{array}{l}4268 \\
(58.5)\end{array}$ & $\begin{array}{c}73 \\
(62.9)\end{array}$ & $\begin{array}{l}8051 \\
(61.3)\end{array}$ \\
\hline \multicolumn{7}{|l|}{ Smoking: number ${ }^{\mathrm{b}}$ and $\%$} \\
\hline Current smoker & $\begin{array}{c}38 \\
(49.4) \\
32\end{array}$ & $\begin{array}{c}2950 \\
(50.5) \\
1539\end{array}$ & $\begin{array}{c}3 \\
(7.7) \\
3\end{array}$ & $\begin{array}{l}504 \\
(6.9) \\
255\end{array}$ & $\begin{array}{c}51 \\
(35.3) \\
35\end{array}$ & $\begin{array}{l}3454 \\
(26.3) \\
1794\end{array}$ \\
\hline Former smoker & $(41.6)$ & $(26.4)$ & $(7.7)$ & $\begin{array}{l}253 \\
(3.5)\end{array}$ & $\begin{array}{c}35 \\
(30.2)\end{array}$ & $(13.7)$ \\
\hline Never smoked & $\begin{array}{c}6 \\
(7.8)\end{array}$ & $\begin{array}{l}1004 \\
(17.2)\end{array}$ & $\begin{array}{c}20 \\
(51.3)\end{array}$ & $\begin{array}{l}5068 \\
(69.5)\end{array}$ & $\begin{array}{c}26 \\
(22.4)\end{array}$ & $\begin{array}{c}6072 \\
(46.2)\end{array}$ \\
\hline
\end{tabular}

${ }^{a}$ Cumulated number of deaths in the first follow-up 3-year period: 23 for stomach cancer and 280 for the other causes; ${ }^{b}$ Not included cases and noncases who did not state their smoking status. 
Table 2 Number of cases/non cases of stomach cancer and age adjusted relative risk, 95\% confidence interval (RR, 95\% Cl) by exposure level to dietary factors in males and females

\begin{tabular}{|c|c|c|c|c|c|c|}
\hline \multirow[b]{2}{*}{ Food item } & \multicolumn{3}{|c|}{ Males } & \multicolumn{3}{|c|}{ Females } \\
\hline & Low $^{a}$ & Medium & High & Low $^{a}$ & Medium & High \\
\hline Fresh meat & $36 / 2175$ & $\begin{array}{c}29 / 2973 \\
0.8,0.5-1.3\end{array}$ & $\begin{array}{c}9 / 424 \\
1.8,0.9-3.7\end{array}$ & |3/2455 & $\begin{array}{c}20 / 3802 \\
1.5,0.7-2.9\end{array}$ & $\begin{array}{c}1 / 619 \\
0.5,0.1-4.0\end{array}$ \\
\hline Processed meat & $32 / 2078$ & $\begin{array}{c}9 / 1135 \\
0.8,0.4-1.7\end{array}$ & $\begin{array}{c}6 / 188 \\
3.4,1.4-8.1\end{array}$ & $7 / 2649$ & $\begin{array}{c}5 / 1433 \\
1.9,0.6-6.3\end{array}$ & $\begin{array}{c}0 \\
-b\end{array}$ \\
\hline Fresh fish & | I/I |46 & $\begin{array}{c}37 / 3128 \\
1.4,0.7-2.7\end{array}$ & $\begin{array}{c}24 / 1285 \\
1.5,0.7-3.1\end{array}$ & $8 / 1220$ & $\begin{array}{c}21 / 409 \mid \\
\mid .0,0.4-2.2\end{array}$ & $\begin{array}{c}6 / 1495 \\
0.6,0.2-1.7\end{array}$ \\
\hline Processed fish & $13 / 1310$ & $\begin{array}{c}25 / 1712 \\
1.6,0.8-3.1\end{array}$ & $\begin{array}{c}9 / 414 \\
2.1,0.9-4.9\end{array}$ & $5 / 1615$ & $\begin{array}{c}4 / 2234 \\
0.7,0.2-2.5\end{array}$ & $\begin{array}{c}2 / 477 \\
1.4,0.3-7.3\end{array}$ \\
\hline Cuttle fish & $8 / 475$ & $\begin{array}{c}36 / 2834 \\
0.9,0.4-2.1\end{array}$ & $\begin{array}{c}28 / 2265 \\
\text { I.0, } 0.4-2.2\end{array}$ & $6 / 694$ & $\begin{array}{c}|2 / 354| \\
0.6,0.2-1.6\end{array}$ & $\begin{array}{c}14 / 2587 \\
1.0,0.4-2.6\end{array}$ \\
\hline Tofu & $13 / 1243$ & $\begin{array}{c}41 / 3185 \\
0.9,0.5-1.7\end{array}$ & $\begin{array}{c}19 / 1210 \\
0.9,0.4-1.8\end{array}$ & $7 / 1150$ & $\begin{array}{c}18 / 4327 \\
0.7,0.3-1.7\end{array}$ & $\begin{array}{c}9 / 1531 \\
0.8,0.3-2.2\end{array}$ \\
\hline Soymilk & |6/1480 & $\begin{array}{c}19 / 1502 \\
1.0,0.5-1.9\end{array}$ & $\begin{array}{c}12 / 438 \\
1.6,0.7-3.4\end{array}$ & $0 / 1372$ & $\begin{array}{c}9 / 2075 \\
-b\end{array}$ & $\begin{array}{c}3 / 887 \\
-b\end{array}$ \\
\hline Liver & $38 / 2470$ & $\begin{array}{c}26 / 2519 \\
0.7,0.4-1.1\end{array}$ & $\begin{array}{c}6 / 476 \\
0.7,0.3-1.7\end{array}$ & ||$/ 3107$ & $\begin{array}{c}16 / 3052 \\
1.6,0.7-3.5\end{array}$ & $\begin{array}{c}7 / 579 \\
2.9,1.1-7.5 *\end{array}$ \\
\hline Fresh milk & $33 / 2708$ & $\begin{array}{c}15 / 1167 \\
1.3,0.7-2.4\end{array}$ & $\begin{array}{c}23 / 1719 \\
0.9,0.5-1.6\end{array}$ & |5/2877 & $\begin{array}{c}6 / 1601 \\
0.9,0.3-2.3\end{array}$ & $\begin{array}{c}16 / 2457 \\
1.3,0.6-2.6\end{array}$ \\
\hline Milk products & $35 / 2770$ & $\begin{array}{c}9 / 431 \\
1.7,0.8-3.6\end{array}$ & $\begin{array}{c}4 / 162 \\
1.5,0.5-4.2\end{array}$ & $9 / 3174$ & $\begin{array}{c}2 / 744 \\
1.2,0.3-5.6\end{array}$ & $\begin{array}{c}3 / 281 \\
3.1,0.8-11.6\end{array}$ \\
\hline Eggs & $13 / 813$ & $\begin{array}{c}29 / 2538 \\
0.8,0.4-1.5\end{array}$ & $\begin{array}{c}32 / 2314 \\
0.8,0.4-1.6\end{array}$ & $16 / 4300$ & $-{ }^{c}$ & $\begin{array}{c}18 / 2744 \\
1.1,0.9-1.3\end{array}$ \\
\hline Seaweed & $17 / 1956$ & $\begin{array}{c}45 / 2640 \\
1.7,1.0-3.0\end{array}$ & $\begin{array}{c}13 / 1047 \\
1.0,0.5-2.1\end{array}$ & $5 / 1668$ & $\begin{array}{c}18 / 3680 \\
1.6,0.6-4.3\end{array}$ & $\begin{array}{c}\mid 1 / 1684 \\
1.8,0.6-5.1\end{array}$ \\
\hline Green and yellow vegetables & $14 / 1308$ & $\begin{array}{c}35 / 268 \mid \\
\mid .0,0.6-1.9\end{array}$ & $\begin{array}{c}25 / 167 \mid \\
0.9,0.5-1.8\end{array}$ & $3 / 817$ & $\begin{array}{c}|7 / 344| \\
\mid .2,0.4-4.2\end{array}$ & $\begin{array}{c}13 / 2803 \\
1.0,0.3-3.5\end{array}$ \\
\hline Other vegetables & $22 / 2243$ & $-^{c}$ & $\begin{array}{c}25 / 1228 \\
1.1,0.9-1.2\end{array}$ & $5 / 2246$ & $-^{c}$ & $\begin{array}{c}10 / 2172 \\
1.1,0.9-1.4\end{array}$ \\
\hline Fruit & $36 / 3270$ & $\begin{array}{c}28 / 2058 \\
0.9,0.6-1.5\end{array}$ & $\begin{array}{c}11 / 357 \\
1.6,0.8-3.3\end{array}$ & $9 / 2336$ & $\begin{array}{c}20 / 3648 \\
1.2,0.6-2.7\end{array}$ & $\begin{array}{c}9 / 1108 \\
1.5,0.6-3.8\end{array}$ \\
\hline Potato, sweet potatoes, taros & $28 / 2504$ & $\begin{array}{c}33 / 2705 \\
0.8,0.5-1.3\end{array}$ & $\begin{array}{c}11 / 443 \\
1.3,0.6-2.6\end{array}$ & | |/1848 & $\begin{array}{c}20 / 4316 \\
0.7,0.4-1.5\end{array}$ & $\begin{array}{c}7 / 899 \\
1.0,0.4-2.6\end{array}$ \\
\hline Margarine & $51 / 3959$ & $\begin{array}{c}10 / 966 \\
1.1,0.5-2.1\end{array}$ & $\begin{array}{c}6 / 423 \\
1.1,0.5-2.6\end{array}$ & 22/3937 & $\begin{array}{c}4 / 1791 \\
0.6,0.2-1.9\end{array}$ & $\begin{array}{c}3 / 904 \\
0.9,0.3-2.9\end{array}$ \\
\hline Use of cooking oild & $9 / 1315$ & $\begin{array}{c}50 / 3221 \\
2.5,1.2-5.2\end{array}$ & $\begin{array}{c}16 / 1035 \\
2.7,1.2-6.1 *\end{array}$ & $6 / 1269$ & $\begin{array}{c}19 / 3976 \\
1.3,0.5-3.3\end{array}$ & $\begin{array}{c}12 / 1749 \\
2.2,0.8-6.0\end{array}$ \\
\hline Miso soup & $|7 /| 60 \mid$ & $\begin{array}{c}48 / 3624 \\
0.9,0.5-1.6\end{array}$ & $\begin{array}{c}10 / 405 \\
1.4,0.7-3.2\end{array}$ & 10/2239 & $\begin{array}{c}25 / 4463 \\
1.0,0.5-2.0\end{array}$ & $\begin{array}{c}2 / 372 \\
0.7,0.2-3.4\end{array}$ \\
\hline Suimono soup ${ }^{\mathrm{e}}$ & $|3 / 156|$ & $\begin{array}{c}25 / 1485 \\
1.7,0.9-3.4\end{array}$ & $\begin{array}{c}8 / 313 \\
2.4,1.0-5.8 *\end{array}$ & $5 / 1866$ & $\begin{array}{c}5 / 2053 \\
0.8,0.2-2.9\end{array}$ & $\begin{array}{c}5 / 353 \\
\text { 4.1. } 1.2-14.2 *\end{array}$ \\
\hline Deep-boiled foods ${ }^{f}$ & $33 / 2769$ & $\begin{array}{c}27 / 2076 \\
0.7,0.4-1.2\end{array}$ & $\begin{array}{c}14 / 748 \\
0.8,0.4-1.5\end{array}$ & $7 / 2685$ & $\begin{array}{c}19 / 3004 \\
1.8,0.7-4.2\end{array}$ & $\begin{array}{c}10 / 1335 \\
1.6,0.6-4.2\end{array}$ \\
\hline Pickled food & $10 / 1438$ & $\begin{array}{c}24 / 1499 \\
1.9,1.0-4.1\end{array}$ & $\begin{array}{c}14 / 465 \\
2.6,1.1-5.8 *\end{array}$ & $5 / 1624$ & $\begin{array}{c}5 / 1865 \\
0.7,0.2-2.6\end{array}$ & $\begin{array}{c}4 / 836 \\
\text { I.I, } 0.3-4.3\end{array}$ \\
\hline Salted food & $27 / 2012$ & $\begin{array}{c}13 / 1017 \\
1.1,0.6-2.2\end{array}$ & $\begin{array}{c}7 / 334 \\
1.8,0.8-4.1\end{array}$ & $8 / 2868$ & $\begin{array}{c}5 / 106 \mid \\
\mid .8,0.6-5.4\end{array}$ & $\begin{array}{c}|/ 3| 5 \\
1.0,0.1-8.0\end{array}$ \\
\hline Sweet cakes & 17/I597 & $\begin{array}{c}15 / 1132 \\
1.0,0.5-2.0\end{array}$ & $\begin{array}{c}15 / 666 \\
1.2,0.6-2.5\end{array}$ & $3 / 1174$ & $\begin{array}{c}5 / 1610 \\
1.3,0.3-5.7\end{array}$ & $\begin{array}{c}6 / 1549 \\
1.5,0.4-5.9\end{array}$ \\
\hline Green tea & $13 / 1226$ & $\begin{array}{c}27 / 2313 \\
1.2,0.6-2.4\end{array}$ & $\begin{array}{c}33 / 2004 \\
1.3,0.7-2.5\end{array}$ & $4 / 1460$ & $\begin{array}{c}14 / 2944 \\
2.0,0.7-6.2\end{array}$ & $\begin{array}{c}15 / 2516 \\
2.2,0.7-6.7\end{array}$ \\
\hline
\end{tabular}

a Reference group; ${ }^{b}$ Not calculated RR due to the small number of cases reported; ${ }^{c}$ Cases and non-cases were grouped together with the low level due to the small number of cases reported; ' Included salad oil; ${ }^{~ J a p a n e s e ~ s o u p ~ s t y l e ; ~}{ }^{\text {fFoods }}$ were deeply boiled in water together with spices. $* P$ for trend $<0.05$.

$(\mathrm{RR}=2.4,95 \% \mathrm{CI}=1.0-5.8, \quad P$ for trend $<0.05)$ and females $(\mathrm{RR}=4.1,95 \% \mathrm{CI}=1.2-14.2, P$ for trend $<0.05)$. Data for males and females combined and controlling for age and sex showed that the high consumption of green and yellow vegetables, tofu, and cuttle fish slightly decreased the risk of stomach cancer $(\mathrm{RR}=0.9$, $95 \% \mathrm{CI}=0.5-1.6, \mathrm{RR}=0.9,95 \% \mathrm{CI}=0.5-1.6$, and $\mathrm{RR}=0.9,95 \%$ $\mathrm{CI}=0.5-1.8$, respectively). The increased risk of stomach cancer associated with the high consumption of processed meat, suimono soup, and the frequent use of cooking oil remained.

Table 3 presents the findings adjusted for sex, age, smoking, and other dietary factors (processed meat, liver, cooking oil, suimono, and pickled food), both including and excluding the first three-year of follow-up. A significant decline in the risk of stomach cancer was found with a high consumption of green and yellow vegetables $(\mathrm{RR}=0.4,95 \% \mathrm{CI}=0.2-0.9, P$ for trend $<0.05)$. Reductions of between 40 and $50 \%$ were also observed for the high consumption of fruit, cuttle fish, tofu, and potatoes, but these associations were not statistically significant. In contrast, the risk of stomach cancer was significantly increased with the high consumption of processed meat $(\mathrm{RR}=2.7,95 \% \mathrm{CI}=1.0-7.4, P$ for trend $<0.05)$ and the frequent use of cooking oil $(\mathrm{RR}=4.0,95 \% \mathrm{CI}=1.3-11.8, P$ for trend $<0.05)$. Elevations in stomach cancer risk were also observed 
Table 3 Number of cases/non cases of stomach cancer and RR, 95\% Cl by exposure level to dietary factors, males and females combined

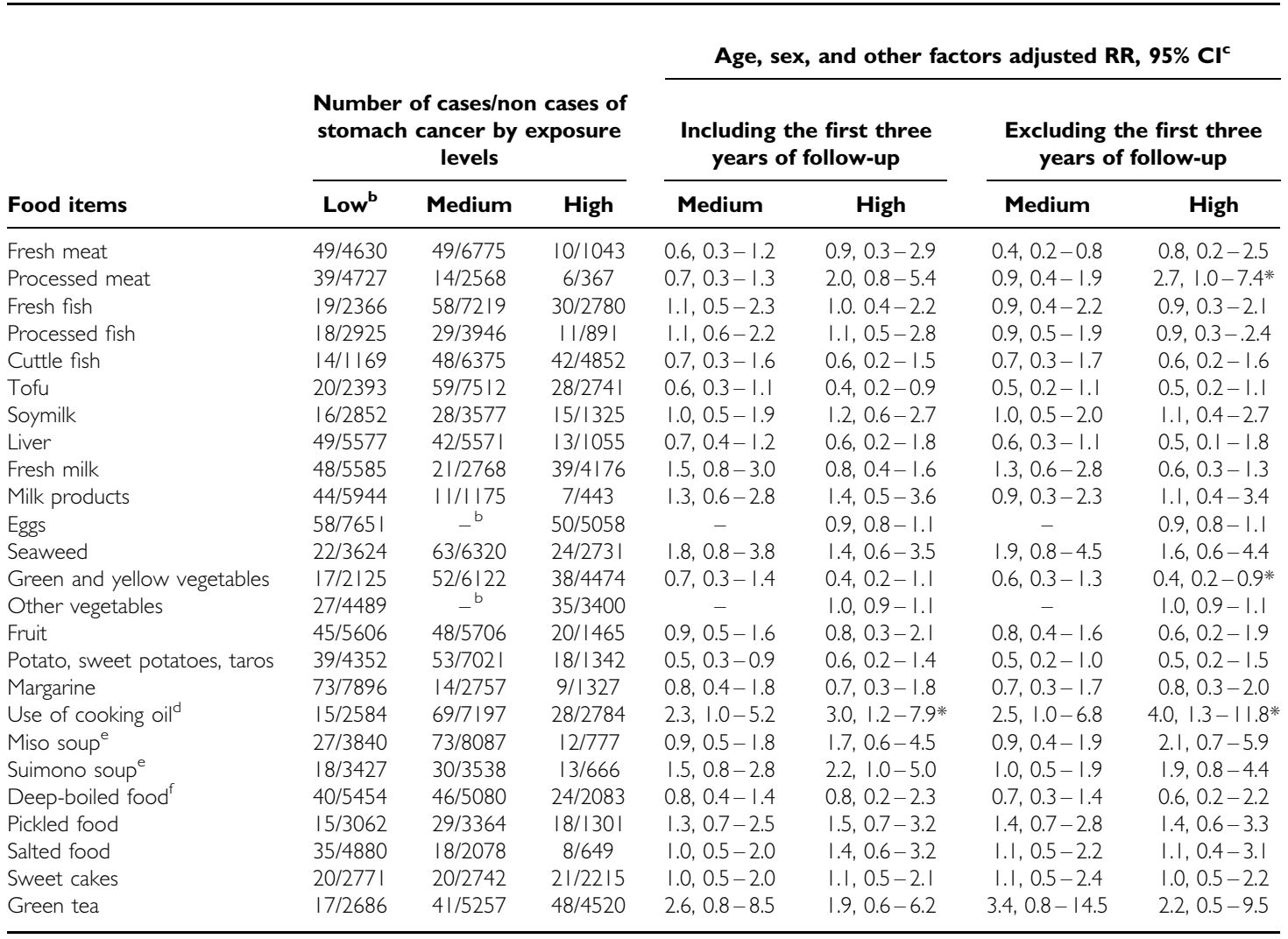

a Reference group; ${ }^{b}$ Cases were grouped together with the low level due to the small number of cases reported; 'The other factors were smoking (current, former, and not currently smoking), processed meat, liver, cooking or salad oil, suimono, and pickled food. Included salad oil; 'Japanese soup style; fFoods were deeply boiled in water together with spices. *P for trend $<0.05$.

with a high consumption of pickled food $(\mathrm{RR}=1.4,95 \% \mathrm{CI}=0.6-$ $3.3)$, miso soup ( $R R=2.1,95 \% \mathrm{CI}=0.7-5.9)$, and suimono soup $(\mathrm{RR}=1.9,95 \% \mathrm{CI}=0.8-4.4)$, but again these were not statistically significant.

\section{DISCUSSION}

Our study subjects were recruited from the Fukuoka general population, and a large number of subjects provided their frequency of food consumption for 25 common food items. The frequency of food consumption and other factors were recorded before diagnosis of stomach cancer and other diseases, thus avoiding recall bias. These several methodological advantages helped us to evaluate the association between individual dietary items and stomach cancer. Our cohort study showed a beneficial effect of green and yellow vegetables and the risk of processed meat and the frequent use of cooking oil. However, despite the moderately large number of cases, there was insufficient power to detect a statistically significant association for many foods, and there were small numbers in most exposure categories of interest. The small number of cases, especially in females, may be responsible for the inconsistencies and a conflicting observation (as in liver and deep-boiled food) between males and females (Table 2). Nevertheless, as fresh foods are rich in vitamins and low in salt and Japanese traditional foods are poor in vitamins and rich in salt, the data are suggestive that a diet high in salt and low in vitamins may be associated with stomach cancer.

Green and yellow vegetables are very rich in vitamin C, and has been found to be protective against stomach cancer in a number of experimental and epidemiological studies. Thus, vitamin $\mathrm{C}$ may inhibit gastric cancer cell growth, be a possible means of blocking the formation of human carcinogenic N-Nitroso compounds, and may reduce nitrite concentration by $43 \%$ (Mirvish et al, 1972; Raineri and Weisburger, 1975; Zhang et al, 2002). A prospective cohort study found a significantly decreased risk of progression to dysplasia or gastric cancer among subjects with high blood ascorbic acid level $(\mathrm{OR}=0.2,95 \% \mathrm{CI}=0.1-0.7)$ (You et al, 2000). A similar observation was seen in a case-control study (OR=0.37, 95\% CI=0.16-0.86) (Boeing et al, 1991). A high consumption of vegetables was associated with a significantly reduced risk of stomach cancer (RR ranked from $0.38-0.40$ and $\mathrm{RR}=0.5,95 \% \mathrm{CI}=0.3-0.9$ ) (Haenszel et al, 1972; Ahn, 1997), as was a high consumption of vegetables and fruit (You et al, 1988; Nomura et al, 1995; Galanis et al, 1998; Ji et al, 1998; Terry et al, 1998). These findings were consistent with our results for green and yellow vegetables $(\mathrm{RR}=0.4,95 \% \mathrm{CI}=0.2-0.9, P$ for trend $<0.05$ ) (Table 3).

Kagawa (1991) confirmed that Japanese preserved foods, such as processed meat, pickled vegetables, and traditional noodles or soup, are rich in sodium and low or null in vitamin C. High salt foods were associated with an increased risk of stomach cancer (Haenszel et al, 1972; Tuyns, 1988; Nazario et al, 1993; Ramon et al, 1993; Lee et al, 1995; Ahn, 1997; Huang et al, 2000). These earlier results are also in general agreement with our finding for high consumption of processed meat $(\mathrm{RR}=2.7,95 \% \mathrm{CI}=1.0-7.4$, $P$ for trend $<0.05)$.

A high frequent use of cooking oil significantly increased the risk of stomach cancer in both males and females (Tables 2 and 3). Deep-oil-fried foods are common traditional Japanese foods (Tsugane et al, 2001; Ogawa et al, 2002) and produce human carci- 
nogens at high cooking oil temperatures. Cooking oil fumes contain high concentrations of human carcinogens, such as $\mathrm{BaP}$ and DBahA, and heterocyclic aromatic amines, due to high frying temperatures (Li et al, 1994; Sinha et al, 1994; Skog et al, 1995). Benzo(a)pyren, chrysene, and dibenzathracene have been detected at significant levels in oil fried vegetables and fish (Sivaswamy et $a l, 1991)$. Frying also leads to the formation of both the aminomethylimidazoquinoline and the carboline types of HAs (Chiu et al, 1998). Another prospective cohort study found that a high consumption of deep-fried food increases the risk of stomach cancer ( $\mathrm{RR}=1.71,95 \% \mathrm{CI}=0.67-4.34)$ (Kato et al, 1992), which was also observed among subjects who consumed fried foods frequently ( $\mathrm{OR}=2.3,95 \% \mathrm{CI}=1.6-3.2)$ ( $\mathrm{Ji}$ et al, 1998).

Changes of drinking and eating habits due to ill health among stomach cancer patients have been well addressed (Jacobsen et al, 1986). A small increase in the risk of stomach cancer among cases exposed to the high consumption of fruit in both males and females before controlling for other dietary factors might be due to changes of drinking and eating habits causing an ill condition among stomach cancer patients (Table 2). After adjustment for sex, age, smoking, and other dietary factors (processed meat, liver, cooking oil, suimono, and pickled food), a slight protective effect of fruit consumption against developing stomach cancer was observed, both including and excluding the first three-year period of follow-up (Table 3).

Our study had certain limitations. We did not obtain information at base line on Helicobacter pylori infection (HP). Among Japanese, HP infection significantly increases the risk of stomach cancer (Blaser et al, 1993; Fukuda et al, 1995; Kikuchi et al, 1995; Watanabe et al, 1997). However, a previous prospective cohort study showed that $H P$ infection significantly increased the risk of stomach cancer in males $(\mathrm{RR}=2.59,95 \% \mathrm{CI}=1.03-6.50)$ but not in females ( $\mathrm{RR}=0.99,95 \% \mathrm{CI}=0.36-2.68)$ (Yamagata et al, 2000). A high consumption of pickled vegetables and miso soup significantly increased $H P$ infection $(\mathrm{OR}=1.9,95 \% \mathrm{CI}=1.10-3.30$ and $\mathrm{OR}=1.60,95 \% \mathrm{CI}=1.03-2.49$, respectively) (Tsugane et al, 1994). High-salt diets contribute to expansion of HP colonisation (Fox et al, 1999), therefore, our present results may be affected by $H P$ infection. Another limitation was that the self-administered questionnaire had not been validated. Many other traditional Japanese foods/recipes that have been reported to be risk factors of stomach cancer (Mochi-glutinous rice cake: OR ranked from $1.03-1.80$, traditional Japanese style salad: $\mathrm{RR}=3.10, \quad 95 \%$ $\mathrm{CI}=1.40-6.85$ ) were not included in the present study (Haenszel et al, 1976; Kato et al, 1992). We believe that our results would have been better if these factors had been considered for controlling possible confounding factors in the analysis models.

\section{ACKNOWLEDGEMENTS}

We especially thank Yukiko Fujino, Yuko Uemura, Yoko Wada and the staff members of the Department of Clinical Epidemiology, IIES, UOEH, for their assistance. We also wish to thank Public Health Authorities in the municipal offices and the Public Health Staff at Miyako Health Center and Munakata Health Center for their kind cooperation. This work was partly supported by a Research Grant-in-aid for Scientific Research on Priority Areas from the Ministry of Education, Culture, Sports, Science and Technology: C-1 (12218216) and C-2 (12218237).

\section{REFERENCES}

Ahn YO (1997) Diet and stomach cancer in Korea. Int J Cancer (Suppl 10): $7-9$

Blaser MJ, Kobayashi K, Cover TL, Cao P, Feurer ID, Perez-Perez GI (1993) Helicobacter pylori infection in Japanese patients with adenocarcinoma of the stomach. Int J Cancer 55: 799-802

Boeing H, Frentzel-Beyme R, Berger M, Berndt V, Gores W, Korner M, Lohmeier R, Menarcher A, Mannl HF, Meinhardt M, Muller R, Ostermeier H, Paul F, Schwemmle K, Wagner KH, Wahrendorf J (1991) Case-control study on stomach cancer in Germany. Int J Cancer 47: 858-864

Chiu CP, Yang DY, Chen BH (1998) Formation of heterocyclic amines in cooked chicken legs. J Food Prot 61: $712-719$

Davis GR (1989) Neoplasms of the stomach. In. Gastrointestinal Disease, Sleisenger MH, Fordtrand JS (eds) pp 745-772 Philadelphia, London, Toronto, Montreal, Tokyo: W.B. Saunders

Fox JG, Dangler CA, Taylor NS, King A, Koh TJ, Wang TC (1999) High-salt diet induces gastric epithelial hyperplasia and parietal cell loss, and enhances Helicobacter pylori colonization in C57BL/6 mice. Cancer Res 59: $4823-4828$

Fujino Y, Mizoue T, Tokui N, Yoshimura T (2001) Prospective study of diabetes mellitus and liver cancer in Japan. Diabetes Metab Res Rev 17: $374-379$

Fukuda H, Saito D, Hayashi S, Hisai H, Ono H, Yoshida S, Oguro Y, Noda T, Sato T, Katoh M, Terada M, Sugimura T (1995) Helicobacter pylori infection, serum pepsinogen level and gastric cancer: a case-control study in Japan. Jpn J Cancer Res 86: 64-71

Galanis DJ, Kolonel LN, Lee J, Nomura A (1998) Intakes of selected foods and beverages and the incidence of gastric cancer among the Japanese residents of Hawaii: a prospective study. Int J Epidemiol 27: 173-180

Haenszel W, Kurihara M, Locke FB, Shimuzu K, Segi M (1976) Stomach cancer in Japan. J Natl Cancer Inst 56: 265-274

Haenszel W, Kurihara M, Segi M, Lee RK (1972) Stomach cancer among Japanese in Hawaii. J Natl Cancer Inst 49: 969-988

Hirayama T (1990) Life-Style and Mortality. Tokyo: Karger

Hisashige A, Kume Y, Yamamoto M, Ogawa T, Nakao S, Ohara H (1983) Analysis of the mortality patterns in an area supplying migratory tunnel workers 1. Regional differences in the mortality patterns. Sangyo Igaku 25: $245-261$
Hoey J, Montvernay C, Lambert R (1981) Wine and tobacco: risk factors for gastric cancer in France. Am J Epidemiol 113: 668-674

Huang XE, Tajima K, Hamajima N, Xiang J, Inoue M, Hirose K, Tominaga S, Takezaki T, Kuroishi T, Tokudome S (2000) Comparison of lifestyle and risk factors among Japanese with and without gastric cancer family history. Int J Cancer 86: $421-424$

Jacobsen BK, Bjelke E, Kvale G, Heuch I (1986) Coffee drinking, mortality, and cancer incidence: results from a Norwegian prospective study. J Natl Cancer Inst 76: $823-831$

Jeyaratnam J, Lee J, Lee HP, Phoon WO (1987) Stomach cancer incidence in a cohort of fishermen in Singapore. Scand J Work Environ Health 13: $524-$ 526

Ji BT, Chow WH, Yang G, McLaughlin JK, Zheng W, Shu XO, Jin F, Gao RN, Gao YT, Fraumeni Jr JF (1998) Dietary habits and stomach cancer in Shanghai, China. Int J Cancer 76: 659-664

Joossens JV, Hill MJ, Elliott P, Stamler R, Lesaffre E, Dyer A, Nichols R, Kesteloot H (1996) Dietary salt, nitrate and stomach cancer mortality in 24 countries. European Cancer Prevention (ECP) and the INTERSALT Cooperative Research Group. Int J Epidemiol 25: 494-504

Kagawa A (1991) Standard Tables of Food Composition in Japan Daigaku Shuppanbu: Joshi Eiyou

Kato I, Tominaga S, Matsumoto K (1992) A prospective study of stomach cancer among a rural Japanese population: a 6-year survey. Jpn J Cancer Res 83: $568-575$

Kikuchi S, Wada O, Nakajima T, Nishi T, Kobayashi O, Konishi T, Inaba Y (1995) Serum anti-Helicobacter pylori antibody and gastric carcinoma among young adults. Research Group on Prevention of Gastric Carcinoma among Young Adults. Cancer 75: 2789-2793

Kneller RW, Gao YT, McLaughlin JK, Gao RN, Blot WJ, Liu MH, Sheng JP, Fraumeni Jr JF (1990) Occupational risk factors for gastric cancer in Shanghai, China. Am J Ind Med 18: 69-78

Kono S, Ikeda M, Tokudome S, Kuratsune M (1988) A case-control study of gastric cancer and diet in northern Kyushu, Japan. Jpn J Cancer Res 79: $1067-1074$ 
Lee JK, Park BJ, Yoo KY, Ahn YO (1995) Dietary factors and stomach cancer: a case-control study in Korea. Int J Epidemiol 24: 33-41

Li S, Pan D, Wang G (1994) Analysis of polycyclic aromatic hydrocarbons in cooking oil fumes. Arch Environ Health 49: 119-122

Mirvish SS, Wallcave L, Eagen M, Shubik P (1972) Ascorbate-nitrite reaction: possible means of blocking the formation of carcinogenic N-nitroso compounds. Science 177: 65-68

Mizoue T, Tokui N, Nishisaka K, Nishisaka S, Ogimoto I, Ikeda M, Yoshimura T (2000) Prospective study on the relation of cigarette smoking with cancer of the liver and stomach in an endemic region. Int J Epidemiol 29: $232-237$

Nazario CM, Szklo M, Diamond E, Roman-Franco A, Climent C, Suarez E, Conde JG (1993) Salt and gastric cancer: a case-control study in Puerto Rico. Int J Epidemiol 22: 790-797

Nomura A (1996) Stomach cancer. In. Cancer Epidemiology and prevention, David S, Joseth F (eds) pp 707-724 New York, Oxford: Oxford University Press

Nomura AM, Stemmermann GN, Chyou PH (1995) Gastric cancer among the Japanese in Hawaii. Jpn J Cancer Res 86: 916-923

Ogawa K, Tsubono Y, Nishino Y, Watanabe Y, Ohkubo T, Watanabe T, Nakatsuka H, Takahashi N, Kawamura M, Tsuji I, Hisamichi S (2002) Dietary sources of nutrient consumption in a rural Japanese population. $J$ Epidemiol 12: 1-8

Parkin DM, Whelan SL, Ferlay J, Raymond L, Young J (1997) Cancer Incidence in Five Continents Vol. VII. IARC Scientific Publication. No. 143. Lyon: IARC, WHO

Pisani P, Parkin DM, Bray F, Ferlay J (1999) Estimates of the worldwide mortality from 25 cancers in 1990. Int J Cancer 83: 18-29

Raineri R, Weisburger JH (1975) Reduction of gastric carcinogens with ascorbic acid. Ann NY Acad Sci 258: 181-189

Ramon JM, Serra L, Cerdo C, Oromi J (1993) Dietary factors and gastric cancer risk. A case-control study in Spain. Cancer 71: 1731-1735

Sinha R, Rothman N, Brown ED, Mark SD, Hoover RN, Caporaso NE, Levander OA, Knize MG, Lang NP, Kadlubar FF (1994) Pan-fried meat containing high levels of heterocyclic aromatic amines but low levels of polycyclic aromatic hydrocarbons induces cytochrome P4501A2 activity in humans. Cancer Res 54: 6154-6159

Sivaswamy SN, Balachandran B, Sivaramakrishnan VM (1991) Presence of polycyclic aromatic hydrocarbons in some South Indian food components. Indian J Exp Biol 29: 611-614

Skog K, Steineck G, Augustsson K, Jagerstad M (1995) Effect of cooking temperature on the formation of heterocyclic amines in fried meat products and pan residues. Carcinogenesis 16: $861-867$
STATA (1999) Statistical Software, Statistics, Data Management Vol. 1. Release 6. College Station, Texas: Stata Press

Terry P, Nyren O, Yuen J (1998) Protective effect of fruits and vegetables on stomach cancer in a cohort of Swedish twins. Int J Cancer 76: 35-37

Tsugane S, Sasaki S, Kobayashi M, Tsubono Y, Sobue T (2001) Dietary habits among the JPHC study participants at baseline survey. Japan Public Health Center-based Prospective Study on Cancer and Cardiovascular Diseases. J Epidemiol 11:S30-S43

Tsugane S, Tei Y, Takahashi T, Watanabe S, Sugano K (1994) Salty food intake and risk of Helicobacter pylori infection. Jpn J Cancer Res 85: $474-478$

Tuyns AJ (1988) Salt and gastrointestinal cancer. Nutr Cancer 11: 229-232

Une H, Esaki H, Osajima K, Ikui H, Kodama K, Hatada K (1995) A prospective study on mortality among Japanese coal miners. Ind Health 33: 67-76

Utoguchi K, Nishisaka S, Tokui N, Mizoue T, Ogimoto I, Yoshimura T (1997) Association between self-reported stressful feeling by SACL and mortality in a Japanese community. J Epidemiol 7: 9-16

Watanabe Y, Kurata JH, Mizuno S, Mukai M, Inokuchi H, Miki K, Ozasa K, Kawai K (1997) Helicobacter pylori infection and gastric cancer. A nested case-control study in a rural area of Japan. Dig Dis Sci 42: 1383-1387

Yamagata H, Kiyohara Y, Aoyagi K, Kato I, Iwamoto H, Nakayama K, Shimizu H, Tanizaki Y, Arima H, Shinohara N, Kondo H, Matsumoto T, Fujishima M (2000) Impact of Helicobacter pylori infection on gastric cancer incidence in a general Japanese population: the Hisayama study. Arch Intern Med 160: $1962-1968$

Yin SN, Li GL, Tain FD, Fu ZI, Jin C, Chen YJ, Luo SJ, Ye PZ, Zhang JZ, Wang GC, Zhang XC, Wu HN, Zhong QC (1989) A retrospective cohort study of leukemia and other cancers in benzene workers. Environ Health Perspect 82: $207-213$

You WC, Blot WJ, Chang YS, Ershow AG, Yang ZT, An Q, Henderson B, Xu GW, Fraumeni Jr JF, Wang TG (1988) Diet and high risk of stomach cancer in Shandong, China. Cancer Res 48: 3518-3523

You WC, Zhang L, Gail MH, Chang YS, Liu WD, Ma JL, Li JY, Jin ML, Hu YR, Yang CS, Blaser MJ, Correa P, Blot WJ, Fraumeni Jr JF, Xu GW (2000) Gastric dysplasia and gastric cancer: Helicobacter pylori, serum vitamin C, and other risk factors. J Natl Cancer Inst 92: 1607-1612

You WC, Zhao L, Chang YS, Blot WJ, Fraumeni Jr JF (1995) Progression of precancerous gastric lesions. Lancet 345: 866-867

Zhang ZW, Abdullahi M, Farthing MJ (2002) Effect of physiological concentrations of vitamin $\mathrm{C}$ on gastric cancer cells and Helicobacter pylori. Gut 50: $165-169$ 